\title{
Data report: grain size distribution of Miocene successions, IODP Expedition 313 Sites M0027, M0028, and M0029, New Jersey shallow shelf ${ }^{1}$
}

\author{
Hisao Ando, ${ }^{2}$ Miho Oyama, ${ }^{3}$ and Futoshi Nanayama ${ }^{4}$
}

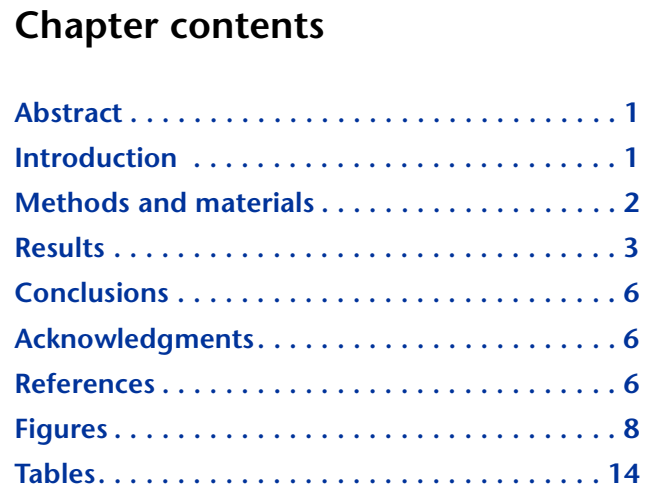

${ }^{1}$ Ando, H., Oyama, M., and Nanayama, F., 2014. Data report: grain size distribution of Miocene successions, IODP Expedition 313 Sites M0027, M0028, and M0029, New Jersey shallow shelf. In Mountain, G., Proust, J.-N., Mclnroy, D., Cotterill, C., and the Expedition 313 Scientists, Proc. IODP, 313: Tokyo (Integrated Ocean Drilling Program Management International, Inc.). doi:10.2204/iodp.proc.313.201.2014 ${ }^{2}$ Ibaraki University, Department of Earth Science, Faculty of Science, 2-1-1 Bunkyo, Mito, Ibaraki 310-8512, Japan. ando@mx.ibaraki.ac.jp ${ }^{3}$ Ibaraki University, Graduate School of Science and Engineering, 2-1-1 Bunkyo, Mito, Ibaraki 3108512, Japan.

${ }^{4}$ Geological Survey of Japan, AIST, Site 7, 1-1-1 Higashi, Tsukuba, Ibaraki 305-8567, Japan.

\section{Abstract}

During Integrated Ocean Drilling Program Expedition 313 on the New Jersey shallow shelf, sandy shallow-marine late Eocene to middle Miocene sediments were successfully drilled at three sites (M0027, M0028, and M0029). From the upper unconsolidated intervals, $\sim 634 \mathrm{~m}$ thick overall, a total of 275 sediment samples were analyzed for grain-size distributions. Average (arithmetic mean) grain size ranges from fine silt to coarse sand, passing from medium silt to medium sand because of the limited occurrence of coarse silt and fine sand. Silty sediments dominate overall, and clay-dominated sediments were not recognized. Average grainsize data plotted on the equivalent intervals of geologic columnar sections show that stratigraphic changes concordantly reflect lithology and sequence stratigraphy at all three sites. Grain-size frequency curves of measured sediment samples can be divided into 16 silt and 8 sand sediment types on the basis of shape, mode position, grain size range, and volume of skewed coarser or finer grain components. Lithostratigraphic changes are concordant to average grain-size curves and sequence stratigraphy, in general.

\section{Introduction}

During Integrated Ocean Drilling Program (IODP) Expedition 313 , Miocene intervals of midshelf clinoforms were drilled in the New Jersey shallow shelf at three sites (M0027, M0028, and M0029), complementing the coastal plain to slope core data sets and building a large "New Jersey transect" across the U.S. Atlantic passive margin. Despite the difficulties of coring in the sandy shallow shelf, Expedition 313 successfully collected a total of $1311 \mathrm{~m}$ of core with $\sim 80 \%$ recovery for target intervals (see the "Expedition 313 summary" chapter [Expedition 313 Scientists, 2010a]). The main goals of Expedition 313 were to estimate the time, amplitudes, rates, and mechanisms of sea level change and to evaluate sequence stratigraphic facies models that predict depositional environments, sediment compositions, and stratal geometries in response to sea level change.

The lithostratigraphic descriptions of split cores show sand-, sandy silt-, and silt-dominated continuous successions of shallowmarine (shoreface to shelf) sediments developed in the late Eocene to middle Miocene that form more than 10 sedimentary cycles. These sediments seem to reflect $50-100 \mathrm{~m}$ sea level changes 
controlled by global eustasy, high sediment supply, and some local factors during the time interval from 34 to $13 \mathrm{Ma}$ (see the "Expedition 313 summary" chapter [Expedition 313 Scientists, 2010a; Miller et al., 2013a, 2013b]).

Our purpose is to detect stratigraphic trends of Miocene successions by analyzing the drilled sediments for characteristics of grain size, grain-size frequency, and changes in distribution and by constructing mean grain-size curves. Saito (1996) and Hoyanagi and Omura (2001) analyzed grain sizes in the Pleistocene muddy successions of the New Jersey shelf slope (Ocean Drilling Program [ODP] Leg 150) and shelf margin (ODP Leg 174A). However, our target intervals are Miocene shallow-marine successions drilled on the New Jersey shallow shelf.

\section{Methods and materials}

\section{Premeasurement treatment of sediment samples}

Siliciclastic sediments drilled from three sites of Expedition 313 on the New Jersey shallow shelf (Fig. F1) often include biogenic materials (e.g., organic matter and calcareous and siliceous biogenic skeletons such as foraminifers, nannoplankton, radiolarians, diatoms, etc.). Before analyzing the sediment grain size, all organic materials were dissolved using the particle degradation treatment described below.

After drying a subsample of 5-8 g taken from each 20 $\mathrm{cm}^{3}$ or $10 \mathrm{~g}$ of sediment, it was first degraded into particles through pounding semisolid parts softly and carefully in an agate mortar using a pestle. To dissolve organic material, the sediment sample first soaked in $5-8 \mathrm{~cm}^{3}$ of $0.1 \mathrm{M} \mathrm{H}_{2} \mathrm{O}_{2}$ solution in a test tube for a day at room temperature. After adding 3-6 $\mathrm{cm}^{3}$ of $0.1 \mathrm{M} \mathrm{H}_{2} \mathrm{O}_{2}$, the tube was then kept in a shaking water bath for $1 \mathrm{~h}$ at $30^{\circ} \mathrm{C}$ and a $100 \mathrm{rpm}$ shaking rate. Following shaking, the sample was kept in a warm water bath at $50^{\circ} \mathrm{C}$ for 1 day. After cooling to ambient temperature, the tube was filled by adding distilled water and centrifuged for $1 \mathrm{~h}$ at $3400 \mathrm{rpm}$. After removing the upper clean layer and adding distilled water, the sediment was centrifuged twice more. The sediment was then dried for a few days in a thermostatic oven. As a last procedure the sediment was again degraded into particles by softly and carefully pounding semisolid parts, using a pestle in an agate mortar. Ultrasonic vibration for particle degradation was not used in order to avoid particle breakage.

\section{Measurement}

We used two analyzers installed at the Geological Survey of Japan, the LA-300 for silt-sized sediments finer than fine sand and the CAMSIZER for sandsized sediments, both of which are made by Horiba Co. Ltd. (www.horiba.com/). The LA-300 is a laser scattering particle-size distribution analyzer with a measurable size range from 0.1 to $600 \mu \mathrm{m}$. Electrical signals corresponding to the intensity of the scattered light are used to calculate the size distribution of particles, based on the Mie scattering theory. In this study, we measured sediment samples under a relative refraction index as 120-001i. After adjustment of the optical axis, samples were put into a dispersion medium chamber and measured with a laser light transmission rate of $85 \%-90 \%$. A data set of each measurement is divided into 64 logarithmically equally spaced classes between 0.1 and $600 \mu \mathrm{m}$. The installed software calculates major statistical parameters.

A particle analyzer with digital image processing (CAMSIZER) uses two digital (CCD) cameras for the measurable range from $30 \mu \mathrm{m}$ to $30 \mathrm{~mm}$. A data set of each measurement is divided into 40 logarithmically equally spaced classes between -3.0 and $6.0 \phi$ with intervals of $0.2 \phi$. Using Microsoft Excel software, four major statistical parameters were calculated.

Tables T1, T2, and T3 show four statistical parameters such as mean, median, mode of grain size, and standard deviation for each sample measurement.

\section{Materials}

A total of 275 sediment samples were measured from the three sites. The measurable horizons at the three sites are approximately within the unconsolidated upper half of the drilled sections, representing thickness ranges of 293, 177, and $164 \mathrm{~m}$ at Sites M0027, M0028, and M0029, respectively, and a total of $634 \mathrm{~m}$.

\section{Site M0027}

A total of 135 unconsolidated sediment samples suitable for measurements were obtained from Cores 313-M0027A-66X (195 meters composite depth [mcd]) to 170R (489 mcd) (293 m thick). Consolidated sediments abundant in authigenic glaucony (glauconite) grains were unfit for analysis from depths below Core $171 \mathrm{R}$ and so were the poorly recoverable horizons above Core $65 \mathrm{X}$.

In general, we took one sample from each core in the silt-sized sediment intervals and from each section in 
the sand-sized sediments, except for horizons disturbed during drilling or core splitting. Of the 135 samples, 99 came from muddy to very fine sandy sediments that were measured using the LA-300, whereas 36 samples from fine to coarse sandy sediments were measured using the CAMSIZER.

\section{Site M0028}

At Site M0028, we selected a total of 80 samples from unconsolidated and well-recovered intervals of Cores 313-M0028A-14R to 38R (257-323 mcd; $66 \mathrm{~m}$ ) and $79 \mathrm{R}$ to $114 \mathrm{R}(412-523 \mathrm{mcd} ; 111 \mathrm{~m})$. We generally took one sample from each core except for the horizons disturbed during drilling or core splitting. The interval between Cores 39R and 78R (323-412 mcd) is heterogeneously consolidated and poorly recovered at large. Among 80 samples, 73 were measured by the LA-300 and the others were measured by the CAMSIZER.

\section{Site M0029}

At Site M0029, a total of 60 samples were selected from unconsolidated intervals of Cores 313M0029A-50R to 84R (280-379 mcd; $99 \mathrm{~m})$ and $111 \mathrm{R}$ to 133R (457-522 mcd; $65 \mathrm{~m}$ ). We generally took one sample from each core. Twelve sand-sized sediments were measured by the CAMSIZER and the rest were measured by the LA-300.

\section{Results}

\section{Types of grain-size frequency curves}

The grain-size frequency curves for the samples from the three sites drawn by the installed software in the LA-300 and CAMSIZER are divided into 16 silt and 8 sand types on the basis of their curve shape, mode position, grain size range, and volume of skewed coarser or finer grain components. These curves reflect altogether the nature of the source area, the erosion processes, and sediment transportation history.

\section{Silt sediment types}

Figure F2 shows the representative histograms and cumulative volume curves of 16 types (Types 1-16) of grain-size frequency distributions in 220 silt samples finer than fine sand. The three most frequent types, namely Types 6,10 , and 7 , reach $45 \%, 14.5 \%$, and $10 \%$, respectively, as a whole and occupy $~ 70 \%$ of the total (Table T4). No other type exceeds $4 \%$. The frequency of types varies depending on the site. Among the three sites, Site M0029 is more variable, though the number of measured samples is the smallest. The following is a brief description of each curve type:
- Types 1 and 2: the mode generally shows symmetrical pyramidal shapes on the fine silt class, but Type 1 has a smaller amount of finer clay fractions. Both types have gently concave left (finer) and concave right (coarser) lower slopes. Although Type 1 is the finest among 16 types, both Types 1 and 2 can be classified as clayey silt. Both of the types are recognized in three samples from Site M0027. Three samples from Site M0028 are Type 1, and one sample from Site M0029 is Type 2.

- Type 3: this type is recognized only in one sample from Site M0029; it is characterized by a bimodal shape with the higher mode on fine silt and the lower on very fine sand. This type is classified as very fine sandy silt.

- Type 4: the mode has a nearly symmetrical, triangular shape with a gently concave right lower slope. This type is classified as silt and is recognized in two samples from both Sites M0027 and M0029.

- Type 5: though similar to Type 6 in its general mode curve shape, Type 5 has an acute peak between fine to medium silt with a more concave and long left slope. Type 5 is classified as silt and is observed in four samples from Site M0027 and in one sample from Site M0029.

- Type 6: this type is the most frequent type found in silty sediment samples from all three of the sites. It reaches $53.5 \%$ and $49.3 \%$ at Sites M0027 and M0028, respectively, but decreases to $20.8 \%$ at Site M0029. This type has a leftward skewed asymmetric shape with a mode on medium silt and gently concave slopes on both sides. Type 6 is classified as silt as well as Types 4 and 5 .

- Type 7: the mode has a pyramidal symmetrical form, both flat sides and a peak at medium silt. It includes $<20 \%$ of very fine to fine sand. Thus, this type is classified as slightly sandy silt. This is the third most common type at the three sites and occurs adjacent to Type 6 horizons.

- Type 8: the mode is somewhat similar in shape to Type 7 except for the convex-up coarser side on coarse silt and very fine sand. This type is classified as sandy silt and is observed in 1-3 samples at each site.

- Type 9: the mode forms a round-top asymmetrical shape with a peak at medium to coarse silt and includes $>20 \%-30 \%$ very fine to medium sand. Type 9 is classified as very sandy silt and is observed in one to four samples of the three sites.

- Type 10: the mode is similar in its asymmetrical triangular general shape to Type 6 , but its peak is situated on medium to coarse silt. Though Type 
10 is also similar to Type 9, it has an angular mode with flat left and slightly concave right sides. Type 10 is the second most common type found at all the three sites. This type is classified as slightly sandy silt. Four types (Types 7-10) can be generally classified as sandy silt.

- Type 11: although classified as poorly sorted sandy silt as well as Type 9, this type is characterized by a mode with convex-up left side and a distinct peak at coarse silt to very fine sand. The mode is somewhat similar to Type 9 in general shape and the flat lower part of the both sides, though the top surfaces differ. Type 11 is recognized in one sample from Site M0027 and in five samples from Site M0029.

- Type 12: the mode has an acute peak on coarse silt to very fine sand with a skewed toward finer, long left lower slope. This can be classified as silty very fine sand. Type 12 was found only in five samples at Site M0029.

- Types 13 and 14: these types are classified as sandy silt, have modes with similar shapes with peaks at medium silt, and have shoulderlike convexity in very fine and fine sand classes. As Type 14 includes more coarser components, its mode has a conspicuous convex form in the right side. This means that Type 14 is coarser than Type 13 as a whole. Type 13 is recognized in two samples at Site M0027 and in six samples at Site M0028, and Type 14 is seen in two samples at Site M0027 and in three samples at Site M0029.

- Types 15 and 16: these types are characteristic bimodal shapes within a wide range of grain size, indicating poorly sorted silt to sand sediments: the mode for Type 15 has a set of left lower and right higher peaks at fine silt and very fine sand, respectively. Type 15 very sandy silt is only detected in three samples at Site M0029. Type 16 mode has two similarly high peaks situated on the coarser side, namely medium silt and fine sand. Furthermore, Type 16 contains common medium sand grains. Type 16 very silty fine sand is recognized in two samples at Site M0027 and in four samples at Site M0029.

\section{Sandy sediment types}

Figure F3 shows the representative histograms and cumulative volume curves of eight types $(\mathrm{A}-\mathrm{H})$ of grain-size frequency distributions in a total of 55 sandy samples from the three sites measured by the CAMSIZER.

Three curve types, namely Types A, B, and C, show monomodal simple curves and occupy $85 \%$ of the total measured samples (Table T4). No other type ex- ceeds $6 \%$ of the total. Their frequency varies depending on sites, though the numbers of measured samples are smaller than in silty sediments. Each type is briefly described below.

Types A-C have monomodal shapes with peaks in medium sand and both upper steep and lower concave slopes, showing relatively well sorted sand sediments. Types D-H are observed only in one or two samples at Site M0027, except for Type F, which is found in a sample at Site M0028. These types are poorly sorted sediments and show characteristic grain-size frequency curves different from Types A-C.

- Type A differs from Types B and C; the mode is skewed toward finer and the shape is asymmetrical, with the gentle concave left slope finer than medium sand. Type A medium to coarse sand is recognized in two samples from each site.

- Type B is characterized by a mode with symmetrical shape with an acute and high (leptokurtic) peak and both steep concave slopes, indicating well-sorted medium to coarse sand deposits. Type $B$ is common at all three sites.

- Type C has the left side steep and leftward-continuing low skirt, showing a small amount of finer components than fine sand. The right half is similar to Type B in the rightward concave shape. Type $\mathrm{C}$ (medium to coarse sand deposits) is abundant at Site M0027 but was not found at Site M0029.

- Type D is characterized by a mode with a central high peak on medium to coarse sand and both sides smooth and flat over a wide range of grain sizes, indicating that this sediment is very poorly sorted. Type D also includes very coarse sand and granule gravel.

- Type E has a trapezoidal shape with a gently rightward-inclined flat top (fine to coarse sand) and symmetrically inclined sides.

- Type F is characterized by a mode with left-side steep slope and right-side gentle slope and a peak between medium and coarse sand. It includes granules and a small amount of small pebbles. Therefore, Type $\mathrm{F}$ granule-bearing medium to coarse sand is a very poorly sorted sediment similar to Types D and G.

- Type G has a conspicuous bimodal shape with the left peak on fine sand and the right peak between coarse and very coarse sand. Type G poorly sorted fine to very coarse sand includes a small amount of granules and small pebbles.

- Type $\mathrm{H}$ is a medium to very coarse sand with granules. Its mode peaks at medium sand, though it includes a large amount of coarse to very coarse 
sand. The mode for Type $H$ has a very steep left slope side and a gentle right slope.

\section{Stratigraphic trends of average grain-size variations}

The four parameters of mean, median, mode, and standard deviation calculated from the measured grain-size data generally show similar stratigraphic trends at each site. Average grain-size (arithmetic mean) data are representatively plotted on the measured intervals of geologic columnar sections in Figures F4, F5, and F6.

Mean grain size of a total of 275 measured sediment samples ranges from silt to coarse sand. Silty sediments dominate as a whole. Clayey silt was recognized only in a few samples from 207 to $196 \mathrm{mcd}$ at Site M0027. Clay-dominated horizons are not detected in our grain-size analyses, though visual core descriptions (VCD) describe the common occurrence of clay sediments (see the "Expedition 313 summary" chapter [Expedition 313 Scientists, 2010a]). It is worth noting that the mean grain size of measured samples from the three sites is differentiated as finemedium silt and medium-coarse sand due to the limited occurrence of coarse silt to fine sand.

\section{Site M0027}

Figure F4 shows the stratigraphic trends of average grain-size variations for 135 measured sediment samples from the interval Cores 313-M0027A-170R to 66X (489-195 mcd). In the intervals 475-415 and 336-197 mcd, medium to coarse silt is largely dominant. The sediments between 208 and 197 mcd are composed of fine silt to clayey silt and are the finest among measured horizons of the three sites. Conspicuous stratigraphic changes in mean grain size are not observed within these silty intervals, but a few subtle fining-upward trends from 30-40 to 10-20 $\mu \mathrm{m}$ can be recognized in the intervals 478-463, 314-295 and 250-240 mcd. Small-scale oscillations and kinks within the 336-197 mcd interval seem to occur near the sequence boundary horizons or to reflect the stacking patterns of sequences described by Miller et al. (2013a). Furthermore, the coarsening-upward trend from 22 to $36 \mu \mathrm{m}$ can be recognized in the lowest interval of $487-478 \mathrm{mcd}$.

In sandy intervals 357-336 mcd and 408-366 mcd, medium to coarse sand ranging from 0.250 to 0.800 $\mathrm{mm}$ is dominant, except for a few intercalated silt laminae/thin layers. The most conspicuous coarsening-upward trend is recognized from 415 to 396 mcd, from medium silt to coarse sand (31-564 $\mu \mathrm{m})$. The coarsening-upward trend continues until 366 mcd, though slight grain size changes from medium to coarse sand occur. This trend corresponds to the upward-shallowing lithostratigraphic changes described in the "Site M0027" chapter (Expedition 313 Scientists, 2010b) and Miller et al. (2013a)

Above the poorly recovered horizon at $366-357 \mathrm{mcd}$, a few oscillations within the $360-806 \mu \mathrm{m}$ range (medium to coarse sand) are recognizable in the 357-336 mcd interval, similar in shape to the equivalent horizon of total gamma ray curves (see the "Site M0027" chapter [Expedition 313 Scientists, 2010b]).

\section{Site M0028}

Mean grain size in silty sediments from measured intervals 523-415 and 323-270 mcd narrowly ranges between 20 and $50 \mu \mathrm{m}$ within medium to coarse silt, showing only subtle stratigraphic changes (Fig. F5). Within the interval $450-415$ mcd, two coarseningupward trends are detectable at 450-435 and 432$416 \mathrm{mcd}$. These seem to correspond to lithology to some extent. It is notable that the interval 441-415 mcd shows finer measured results due to transitional sediments from very fine/fine sandy silt to silty very fine sand, because the same interval was mainly defined as very fine/fine sand in the lithology column by VCD (see the "Site M0028" chapter [Expedition 313 Scientists, 2010c]). As sandy sediments are measured only in seven samples from Site M0028, stratigraphic changes are not well defined.

\section{Site M0029}

Though there are fewer measured samples at this site, silty sediments at Site M0029 are coarser than at Sites M0027 and M0028, ranging from 15 to $100 \mu \mathrm{m}$ (Fig. F5). Mean grain size shows more distinctive stratigraphic changes between medium and very fine sand at the intervals 522-475 mcd and especially 378-310 mcd, generally corresponding to lithology and sequence stratigraphy (see the "Site M0029" chapter [Expedition 313 Scientists, 2010d]). On the other hand, sandy sediments are slightly finer than at Site M0027.

\section{Stratigraphic trends of types of grain-size distribution}

Types of grain-size distribution are not necessarily quantitative characteristics; however, grain size changes at all three sites are considerably concordant to lithology, average grain-size curves, and sequence stratigraphy (Figs. F4, F5, and F6).

\section{Site M0027}

Among the measured silty sediment samples, Type 6 is common and is associated with Types 5 and 7-10. The coarsening-upward trend in mean grain size 
from 415 to 396 mcd appears to be parallel to the change from Type 9 to Type 16 . Type $\mathrm{C}$ is abundant in the sandy sediment interval 409-366 mcd, except for the lowest three samples, which are Types A and $\mathrm{B}$, and for one sample at $378.24 \mathrm{mcd}$, which is Type H. In the upper sandy interval 357-336 mcd, frequent changes among seven types (A-G) generally seem to correspond to a few small-scale oscillations in average grain size, suggesting some relation to the glauconite-bearing lithology (see the "Site M0027" chapter [Expedition 313 Scientists, 2010b]).

\section{Site M0028}

As silty sediments dominate among the measured samples, Type 6 is common and is associated with Types 7-10 as at Site M0027. In the interval 440-424 mcd, the upper part of Sequence m5.34, Type 13 is common. The interval $450-415$ mcd shows two subtle coarsening-upward trends in mean grain size, whereas types of grain-size distributions also change twice concordantly in general. Seven measured sandy samples are divided into two samples each of Type A, B, and C and one sample of Type F.

\section{Site M0029}

Curves of both mean grain size and type of grain-size distribution show nearly the same trends, especially above $360 \mathrm{mcd}$, also broadly corresponding to lithology and sequence stratigraphy. Some turnoff points in the type of grain-size distribution and mean grain size in some cases correspond to sequence boundaries (e.g., Sequences $\mathrm{m} 4.2$ and m.4.1). Therefore, this means that both parameters are closely related to each other.

\section{Conclusions}

We analyzed grain-size distributions of a total of 275 sediment samples from unconsolidated Miocene horizons from three sites (135 samples at Site M0027, 80 samples at Site M0028, and 60 samples at Site M0029). Their horizons cover approximately the upper half of Sites M0027, M0028, and M0029, ranging 293, 177, and $164 \mathrm{~m}$, respectively, a total interval of $634 \mathrm{~m}$. Mean grain size of measured samples from three sites ranges from silt to coarse sand; however, it is differentiated to fine-medium silt and mediumcoarse sand due to a limited occurrence of coarse silt to fine sand. Silty sediments dominate as a whole, and clay-dominated sediments were not recognized. Mean grain-size data plotted on the equivalent intervals of geologic columnar sections show several stratigraphic changes concordantly reflecting lithology and sequence stratigraphy at all three sites. Grainsize frequency curves of silty sediment samples mea- sured by the laser scattering particle size distribution analyzer can be divided into 16 types on the basis of the mode shape and position, range of grain size, and volume of skewed coarser or finer grain components. Grain-size frequency curves of sandy sediments measured by particle analyzer with digital image processing can be also divided into 8 types. These types of grain-size frequency distributions also show several stratigraphic changes considerably concordant to lithology mean grain-size curves and sequence stratigraphy in general.

\section{Acknowledgments}

We thank the Integrated Ocean Drilling Program (IODP), ECORD Science Operator (EOS), and Bremen Core Repository (BCR) staff for helping and supporting our sediment sampling. We also thank Dr. Gregory S. Mountain and Dr. Jean-Noel Proust and scientists of Expedition 313 for giving an opportunity to contribute this paper to the IODP publication and their collaboration during the onshore party and the postcruise meeting. We appreciate Dr. James V. Browning of Rutgers University for helpful reviews of the original manuscript. This research has been financially supported in part by Japan Drilling Earth Science Consortium (J-DESC) and Japan Agency for Marine-Earth Science and Technology (JAMSTEC).

\section{References}

Expedition 313 Scientists, 2010a. Expedition 313 summary. In Mountain, G., Proust, J.-N., McInroy, D., Cotterill, C., and the Expedition 313 Scientists, Proc. IODP, 313: Tokyo (Integrated Ocean Drilling Program Management International, Inc.). doi:10.2204/ iodp.proc.313.101.2010

Expedition 313 Scientists, 2010b. Site M0027. In Mountain, G., Proust, J.-N., McInroy, D., Cotterill, C., and the Expedition 313 Scientists, Proc. IODP, 313: Tokyo (Integrated Ocean Drilling Program Management International, Inc.). doi:10.2204/iodp.proc.313.103.2010

Expedition 313 Scientists, 2010c. Site M0028. In Mountain, G., Proust, J.-N., McInroy, D., Cotterill, C., and the Expedition 313 Scientists, Proc. IODP, 313: Tokyo (Integrated Ocean Drilling Program Management International, Inc.). doi:10.2204/iodp.proc.313.104.2010

Expedition 313 Scientists, 2010d. Site M0029. In Mountain, G., Proust, J.-N., McInroy, D., Cotterill, C., and the Expedition 313 Scientists, Proc. IODP, 313: Tokyo (Integrated Ocean Drilling Program Management International, Inc.). doi:10.2204/iodp.proc.313.105.2010

Hoyanagi, K., and Omura, A., 2001. Data report: grain-size analysis of Pleistocene cores from ODP Sites 1071, 1072, and 1073, New Jersey margin. In Christie-Blick, N., Austin, J.A., Jr., and Malone, M.J. (Eds.), Proc. ODP, Sci. Results, 174A: College Station, TX (Ocean Drilling Program), 1-18. doi:10.2973/odp.proc.sr.174A.159.2002 
Miller, K.G., Browning, J.V., Mountain, G.S., Bassetti, M.A., Monteverde, D., Katz, M.E., Inwood, J., Lofi, J., and Proust, J.-N., 2013a. Sequence boundaries are impedance contrasts: core-seismic-log integration of Oligocene-Miocene sequences, New Jersey shallow shelf. Geosphere, 9(5):1257-1285. doi:10.1130/GES00858.1

Miller, K.G., Mountain, G.S., Browning, J.V., Katz, M.E., Monteverde, D., Sugarman, P.J., Ando, H., Bassetti, M.A., Bjerrum, C.J., Hodgson, D., Hesselbo, S., Karakaya, S., Proust, J.-N., and Rabineau, M., 2013b. Testing sequence stratigraphic models by drilling Miocene foresets on the New Jersey shallow shelf. Geosphere, 9(5):1236-1256. doi:10.1130/GES00884.1
Saito, Y., 1996. Grain-size and sediment-color variations of Pleistocene slope sediments off New Jersey. In Mountain, G.S., Miller, K.G., Blum, P., Poag, C.W., and Twichell, D.C. (Eds.), Proc. ODP, Sci. Results, 150: College Station, TX (Ocean Drilling Program), 229-239. doi:10.2973/odp.proc.sr.150.018.1996

Initial receipt: 28 February 2013

Acceptance: 21 February 2014

Publication: 16 May 2014

MS 313-201 
Figure F1. Location of Sites M0027, M0028, and M0029 on the New Jersey continental margin (from Expedition 313 Scientists, 2010a). MAT = Mid-Atlantic Transect, ODP = Ocean Drilling Program, DSDP = Deep Sea Drilling Project.

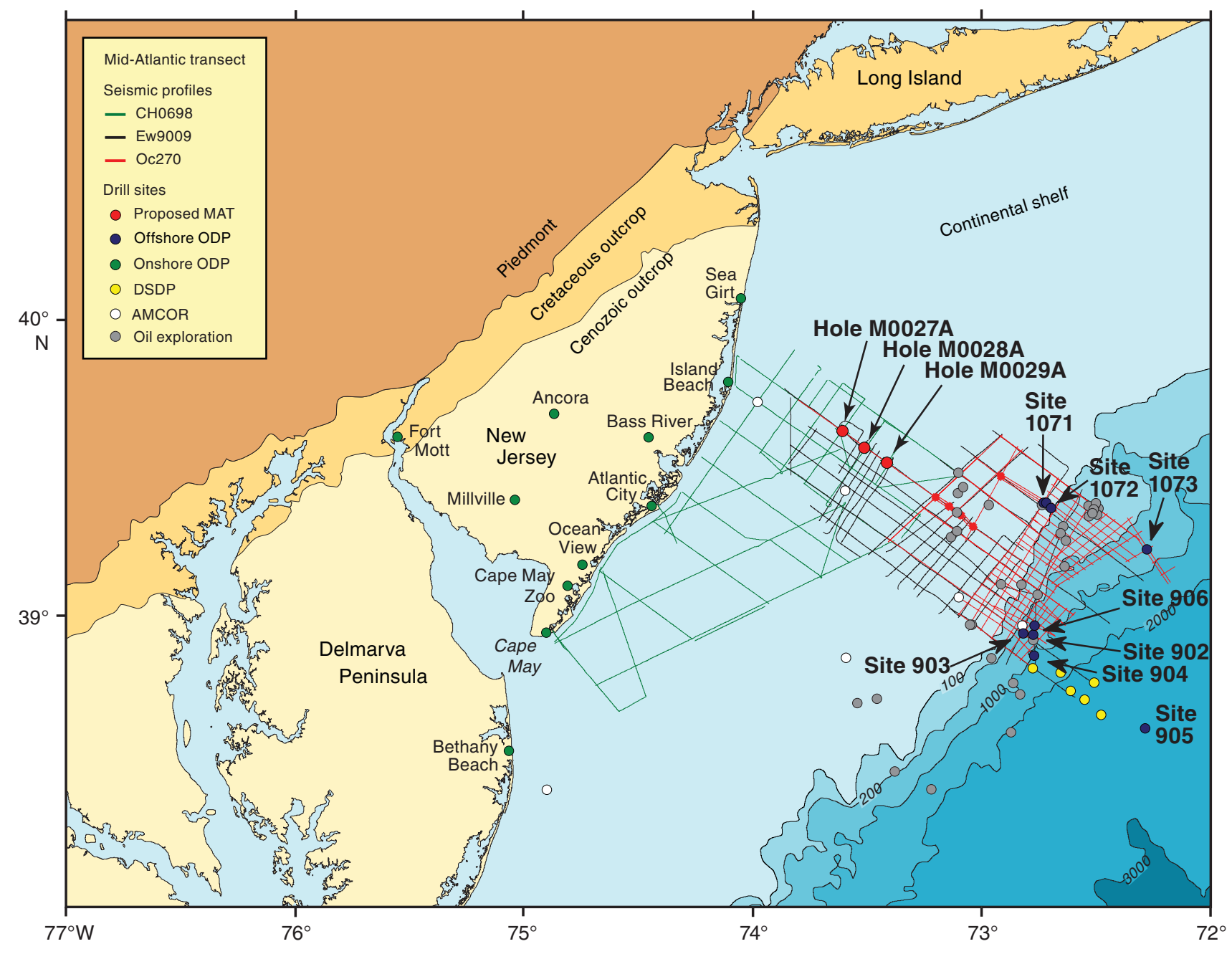


Figure F2. Sixteen types of grain-size frequency histograms and curves recognized in silty sediments, Sites M0027, M0028, and M0029. Left volume axes are somewhat different depending on histograms.
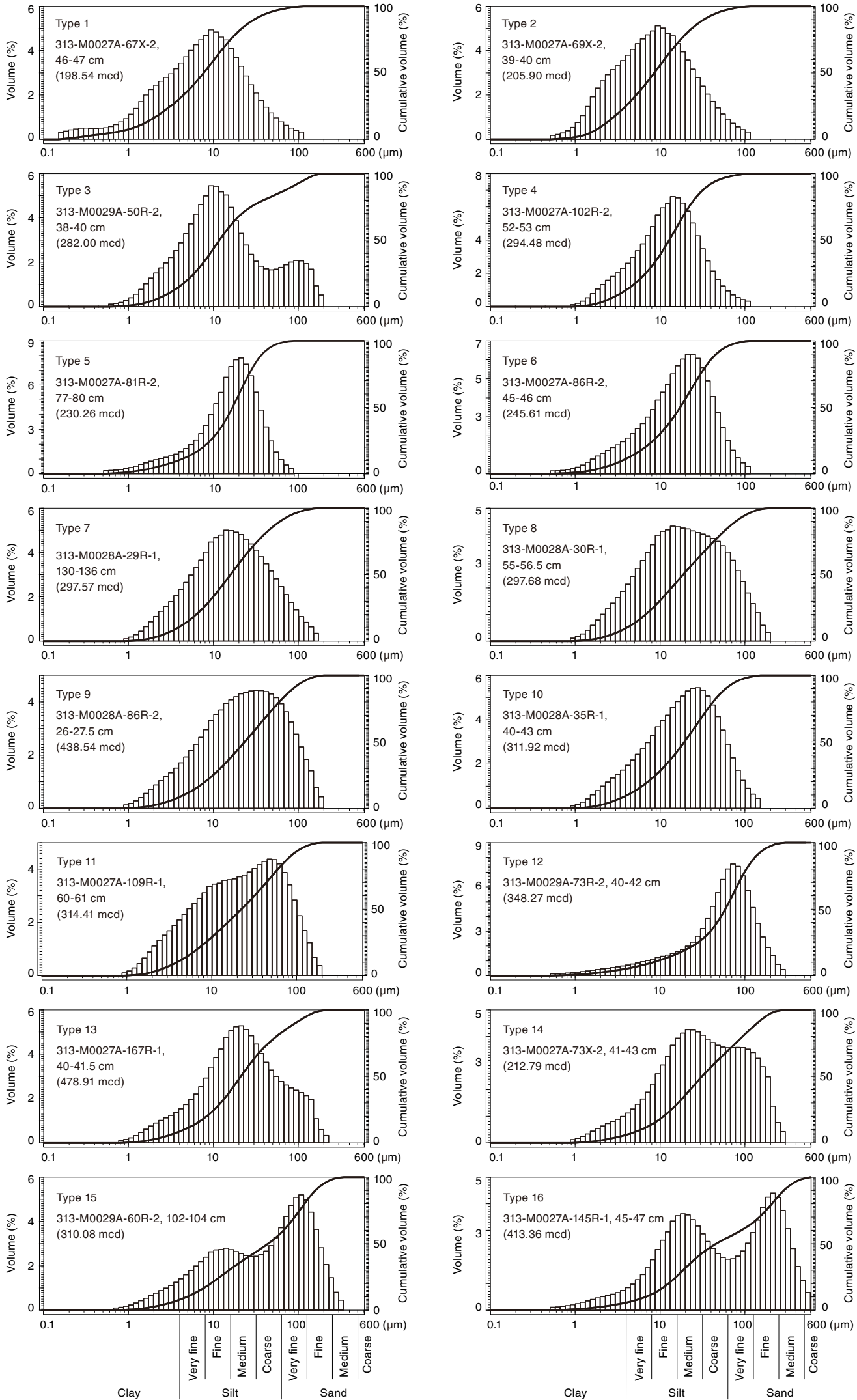
Figure F3. Eight types of grain-size frequency histograms and curves recognized in sandy sediments, Hole M0027A.
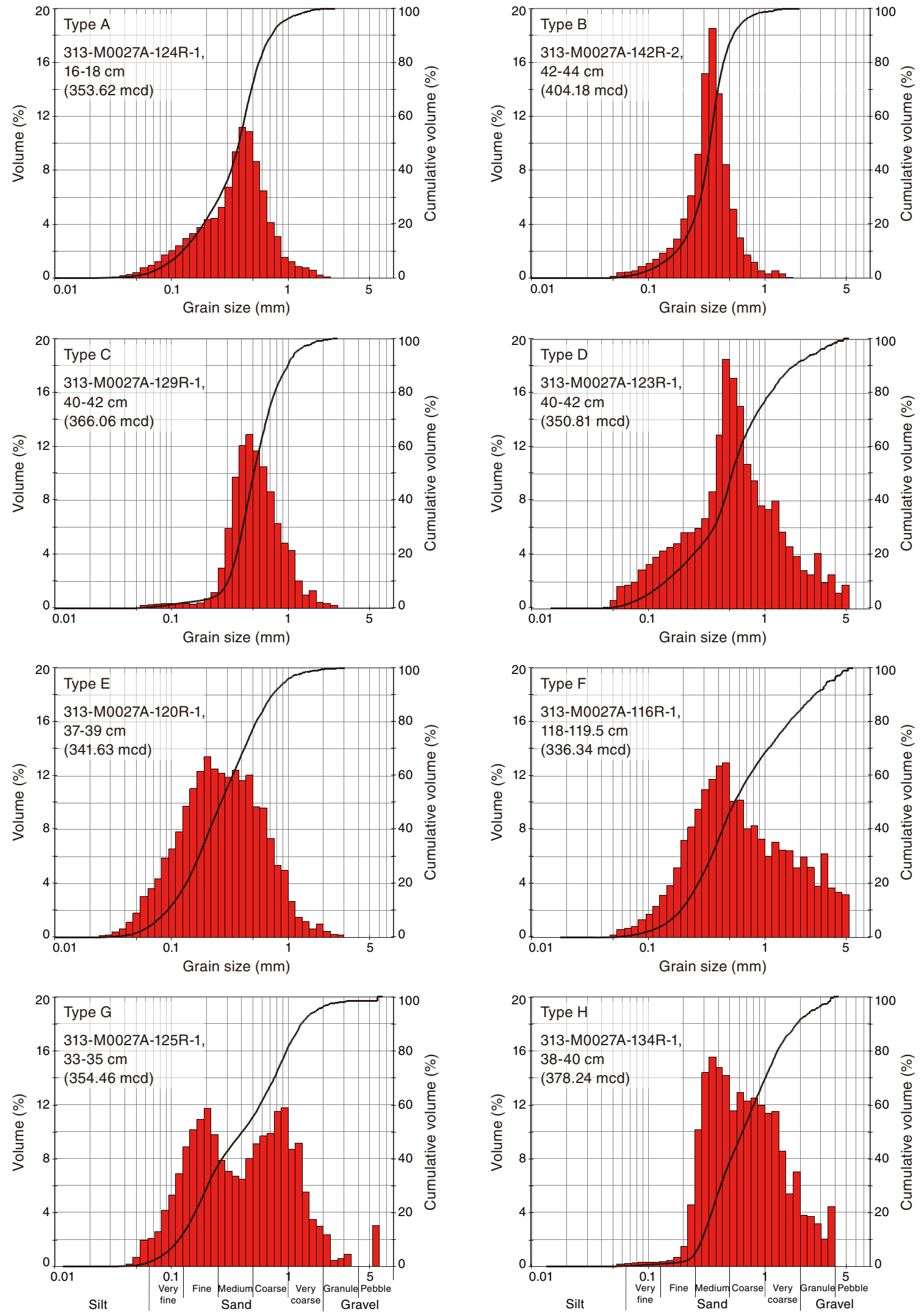
Figure F4. Stratigraphic trends of average grain-size variations and types of grain-size distribution, Site M0027. Core recovery and lithology column after Expedition 313 Scientists (2010b), reflector column after Miller et al. (2013a). Grain size columns: black diamonds and solid lines indicate silty sediment samples and measurements by laser scattering particle size distribution analyzer (LA-300), colored squares (green $=$ Type A, orange $=$ Type B, red = Type C, brown = Type D, light green = Type E, gray = Type F, purple = Type G, black = Type H) and thin red solid lines indicate sandy samples measured by particle analyzer with digital image processing (CAMSIZER). Types A-H shown in Figure F3; Types 1-16 (grain-size distribution in silty sediments) shown in Figure F2. m4.1m5.7 = sequence boundaries, MFS = maximum flooding surface, $\mathrm{TS}=$ transgressive surface. vf $=$ very fine, $\mathrm{f}=$ fine, $\mathrm{m}=$ medium, $\mathrm{c}=$ coarse.

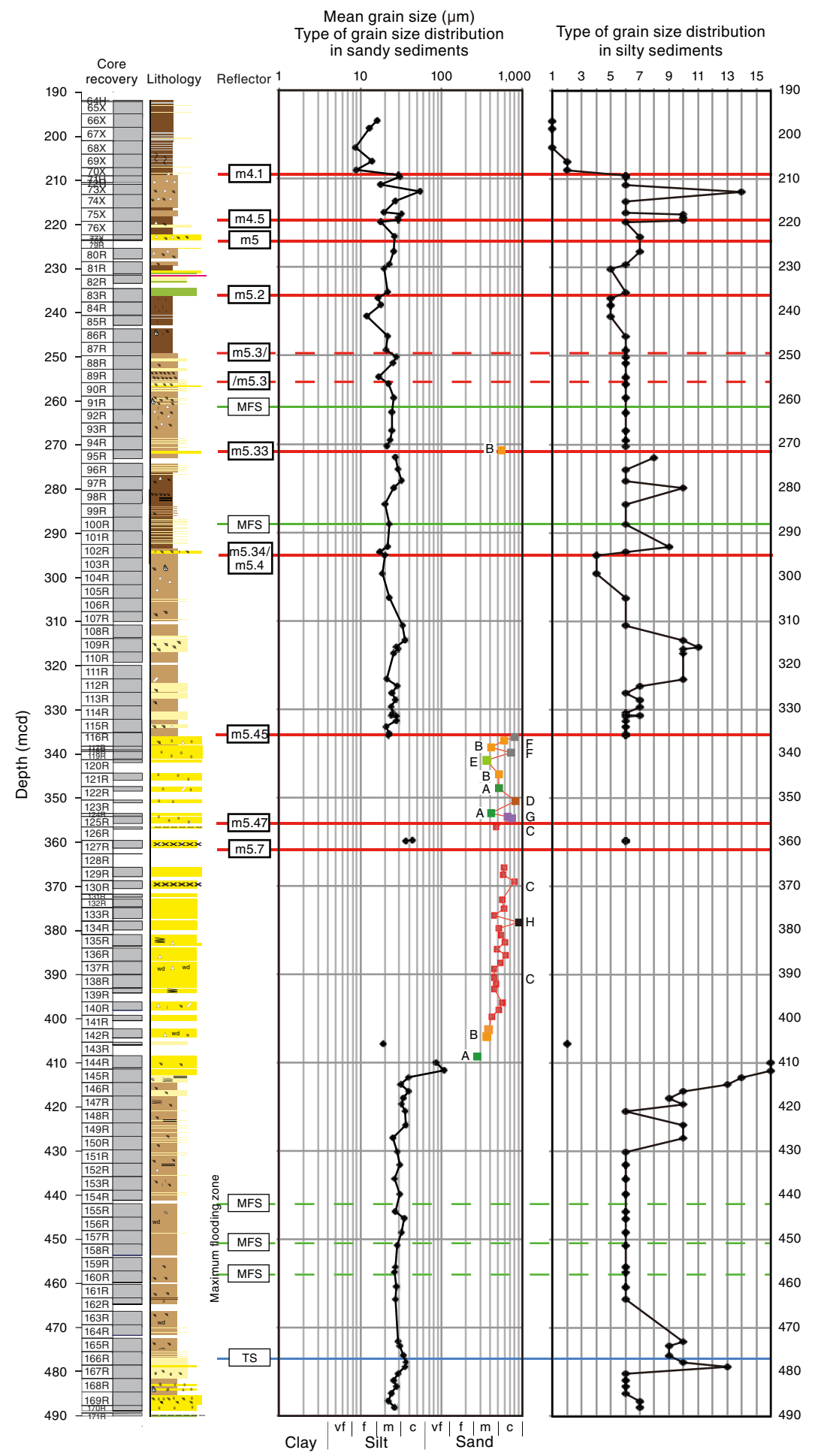


Figure F5. Stratigraphic trends of average grain-size variations and types of grain-size distribution, Site M0028. See Figure F4 for color and symbol definitions. Core recovery column from the "Site M0028" chapter (Expedition 313 Scientists, 2010c).

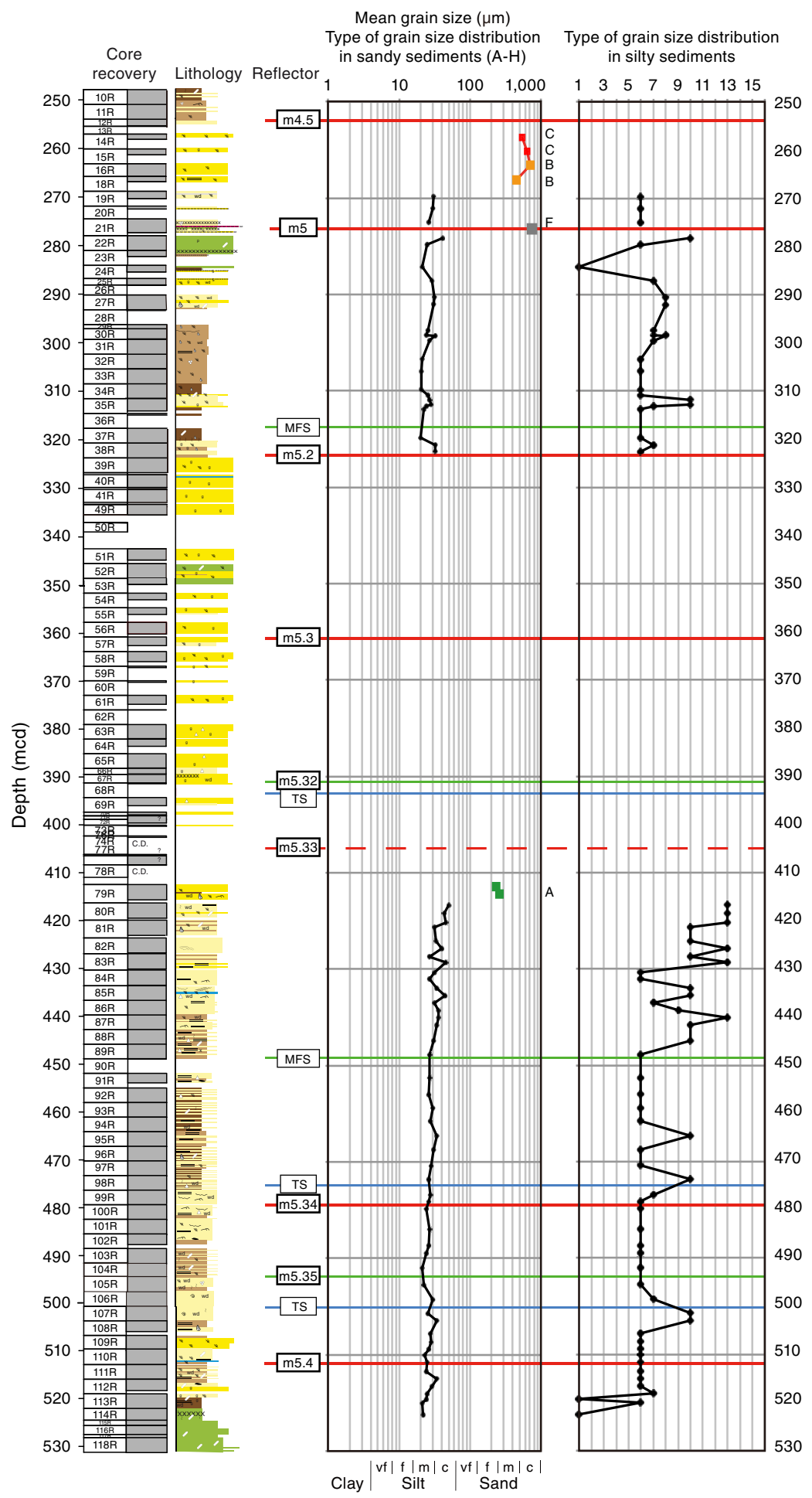


Figure F6. Stratigraphic trends of average grain-size variations and types of grain-size distribution, Site M0029. See Figure F4 for color and symbol definitions. Core recovery column from the "Site M0029" chapter (Expedition 313 Scientists, 2010d).

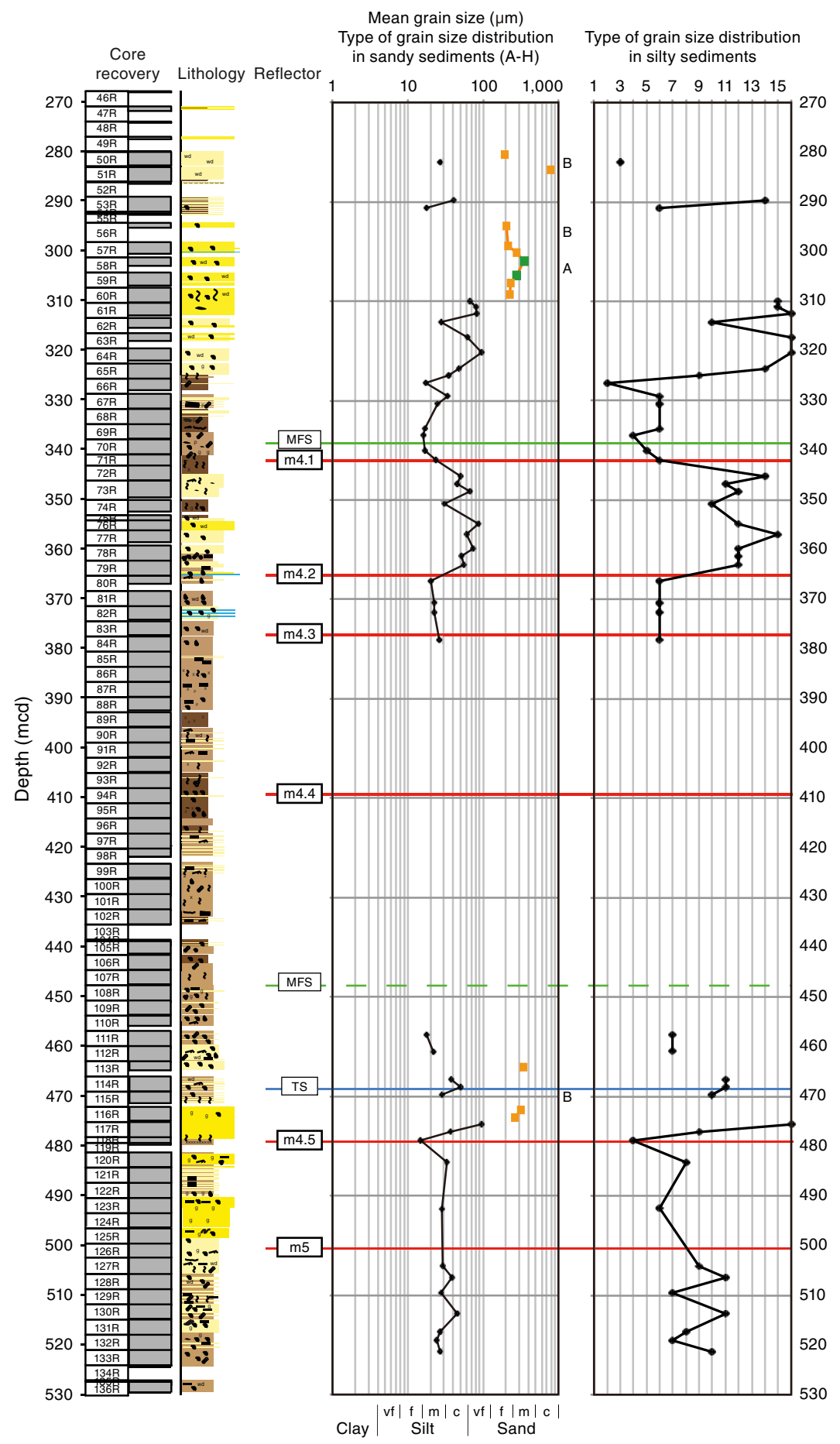


Table T1. Grain-size analysis data, Hole M0027A. (Continued on next page.)

\begin{tabular}{|c|c|c|c|c|c|c|}
\hline \multirow[b]{2}{*}{ Core, section } & \multirow{2}{*}{$\begin{array}{l}\text { Depth } \\
\text { (mcd) }\end{array}$} & \multicolumn{4}{|c|}{ Grain size $(\mu \mathrm{m})$} & \multirow{2}{*}{$\begin{array}{c}\text { Type of } \\
\text { distribution }\end{array}$} \\
\hline & & Mean & Median & Mode & $\sigma$ & \\
\hline \multicolumn{7}{|l|}{ 313-M0027A- } \\
\hline $66 \mathrm{X}-2$ & 196.75 & 16.307 & 8.123 & 9.472 & 22.755 & 1 \\
\hline $67 X-2$ & 198.54 & 12.86 & 7.713 & 9.455 & 15.760 & 1 \\
\hline $68 X-2$ & 202.85 & 8.785 & 6.076 & 9.419 & 9.028 & 1 \\
\hline $69 X-2$ & 205.90 & 14.094 & 8.579 & 9.450 & 16.200 & 2 \\
\hline $70 X-1$ & 207.88 & 8.881 & 6.576 & 9.385 & 8.389 & 2 \\
\hline $70 X-2$ & 209.06 & 29.497 & 19.293 & 21.323 & 31.358 & 6 \\
\hline $71 \mathrm{H}-1$ & 209.47 & 30.699 & 21.043 & 24.414 & 30.146 & 6 \\
\hline $73 X-1$ & 211.37 & 17.768 & 14.712 & 18.627 & 13.880 & 6 \\
\hline $73 X-2$ & 212.79 & 53.927 & 31.258 & 21.340 & 55.781 & 14 \\
\hline $74 X-2$ & 215.05 & 27.306 & 20.811 & 24.444 & 24.174 & 6 \\
\hline $75 X-1$ & 217.53 & 19.496 & 14.631 & 18.573 & 17.180 & 6 \\
\hline $75 X-2$ & 218.04 & 32.515 & 21.579 & 24.375 & 32.728 & 10 \\
\hline $75 X-2$ & 218.74 & 29.517 & 19.674 & 24.383 & 29.571 & 10 \\
\hline $75 X-3$ & 219.24 & 29.219 & 18.397 & 21.269 & 30.398 & 10 \\
\hline $76 X-1$ & 219.64 & 17.786 & 13.082 & 16.227 & 16.712 & 6 \\
\hline $77 X-1$ & 223.06 & 26.237 & 17.501 & 18.597 & 26.649 & 7 \\
\hline 80R-1 & 226.41 & 26.081 & 15.736 & 14.195 & 28.032 & 7 \\
\hline 81R-1 & 229.26 & 23.066 & 17.692 & 21.296 & 20.153 & 6 \\
\hline $81 \mathrm{R}-2$ & 230.26 & 19.456 & 16.821 & 21.246 & 14.095 & 5 \\
\hline $84 \mathrm{R}-2$ & 238.54 & 17.980 & 14.962 & 18.630 & 14.184 & 6 \\
\hline $83 \mathrm{R}-2$ & 235.53 & 21.587 & 14.343 & 16.239 & 23.669 & 5 \\
\hline $83 R-3$ & 236.91 & 16.365 & 13.263 & 16.214 & 13.165 & 5 \\
\hline 85R-1 & 241.01 & 11.978 & 9.721 & 10.816 & 9.392 & 5 \\
\hline $86 \mathrm{R}-2$ & 245.61 & 21.880 & 17.264 & 21.359 & 18.421 & 6 \\
\hline 87R-2 & 248.65 & 20.583 & 15.546 & 21.270 & 18.182 & 6 \\
\hline 88R-1 & 250.26 & 27.831 & 21.166 & 27.900 & 24.596 & 6 \\
\hline 88R-2 & 251.76 & 25.019 & 20.123 & 27.945 & 20.763 & 6 \\
\hline $89 \mathrm{R}-2$ & 254.88 & 17.045 & 13.116 & 16.232 & 14.856 & 6 \\
\hline 90R-1 & 256.34 & 22.217 & 17.654 & 21.336 & 18.370 & 6 \\
\hline 91R-1 & 259.51 & 26.018 & 20.962 & 27.919 & 21.154 & 6 \\
\hline $92 \mathrm{R}-2$ & 262.94 & 24.495 & 19.186 & 24.426 & 20.802 & 6 \\
\hline 93R-2 & 266.91 & 24.698 & 18.421 & 21.339 & 22.193 & 6 \\
\hline 94R-1 & 269.02 & 23.092 & 18.955 & 24.452 & 18.637 & 6 \\
\hline 94R-2 & 270.58 & 21.154 & 16.618 & 21.316 & 18.013 & 6 \\
\hline 95R-1 & 271.45 & 543.422 & 440.000 & 407.000 & 430.983 & B \\
\hline $95 \mathrm{R}-2$ & 272.97 & 27.191 & 15.929 & 14.168 & 29.128 & 8 \\
\hline 96R-2 & 275.88 & 29.238 & 24.354 & 31.952 & 23.283 & 6 \\
\hline 97R-1 & 278.36 & 32.212 & 24.875 & 31.988 & 27.908 & 6 \\
\hline 97R-2 & 279.86 & 25.614 & 18.133 & 24.371 & 24.198 & 10 \\
\hline 99R-1 & 283.55 & 19.963 & 16.193 & 21.274 & 15.767 & 6 \\
\hline 100R-2 & 288.20 & 22.627 & 17.334 & 21.336 & 19.863 & 6 \\
\hline $102 \mathrm{R}-1$ & 293.17 & 21.687 & 16.751 & 24.376 & 18.798 & 9 \\
\hline $102 \mathrm{R}-2$ & 294.48 & 17.187 & 12.830 & 14.228 & 15.804 & 6 \\
\hline $102 \mathrm{R}-2$ & 295.28 & 20.330 & 14.636 & 16.249 & 19.279 & 4 \\
\hline 104R-1 & 299.34 & 18.904 & 15.172 & 18.634 & 15.568 & 4 \\
\hline 106R-1 & 304.89 & 22.776 & 18.692 & 24.405 & 18.394 & 6 \\
\hline $108 \mathrm{R}-1$ & 311.16 & 32.674 & 23.828 & 36.639 & 29.899 & 6 \\
\hline 109R-1 & 314.41 & 35.175 & 22.371 & 48.142 & 35.260 & 10 \\
\hline 109R-2 & 315.90 & 27.661 & 19.982 & 27.935 & 25.545 & 11 \\
\hline 109R-3 & 316.33 & 29.392 & 20.980 & 31.957 & 27.725 & 10 \\
\hline $110 \mathrm{R}-1$ & 317.25 & 26.093 & 17.848 & 21.328 & 25.200 & 10 \\
\hline $112 \mathrm{R}-1$ & 323.25 & 21.178 & 16.182 & 21.331 & 18.503 & 10 \\
\hline $112 \mathrm{R}-2$ & 324.82 & 28.539 & 18.013 & 18.605 & 29.672 & 7 \\
\hline $113 \mathrm{R}-1$ & 326.36 & 24.552 & 17.873 & 21.304 & 23.011 & 6 \\
\hline 113R-2 & 327.93 & 27.139 & 18.407 & 21.319 & 26.769 & 7 \\
\hline $114 \mathrm{R}-1$ & 329.49 & 23.679 & 16.487 & 21.318 & 22.971 & 7 \\
\hline 114R-2 & 330.96 & 25.279 & 19.263 & 24.429 & 22.629 & 6 \\
\hline 114R-2 & 331.23 & 24.881 & 17.607 & 21.287 & 23.663 & 6 \\
\hline $114 \mathrm{R}-2$ & 331.45 & 23.756 & 16.765 & 21.265 & 22.894 & 7 \\
\hline 114R-2 & 331.66 & 27.744 & 20.924 & 27.916 & 24.734 & 6 \\
\hline 115R-1 & 332.55 & 27.449 & 21.308 & 27.971 & 23.757 & 6 \\
\hline 115R-2 & 334.05 & 20.562 & 14.695 & 21.255 & 19.503 & 6 \\
\hline 116R-1 & 335.62 & 22.753 & 17.859 & 21.352 & 19.637 & 6 \\
\hline 116R-1 & 336.02 & 22.415 & 18.008 & 24.380 & 18.735 & 6 \\
\hline 116R-1 & 336.34 & 796.301 & 494.000 & 467.500 & 788.694 & $\mathrm{~F}$ \\
\hline 116R-2 & 337.05 & 586.988 & 484.000 & 537.000 & 416.435 & B \\
\hline 117R-1 & 338.68 & 411.322 & 336.000 & 354.500 & 307.021 & B \\
\hline 119R-1 & 339.93 & 724.807 & 440.000 & 467.500 & 786.590 & $\mathrm{~F}$ \\
\hline
\end{tabular}


Table T1 (continued).

\begin{tabular}{|c|c|c|c|c|c|c|}
\hline \multirow[b]{2}{*}{ Core, section } & \multirow{2}{*}{$\begin{array}{l}\text { Depth } \\
\text { (mcd) }\end{array}$} & \multicolumn{4}{|c|}{ Grain size $(\mu \mathrm{m})$} & \multirow{2}{*}{$\begin{array}{c}\text { Type of } \\
\text { distribution }\end{array}$} \\
\hline & & Mean & Median & Mode & $\sigma$ & \\
\hline 120R-1 & 341.63 & 359.917 & 265.000 & 203.500 & 323.916 & $\mathrm{E}$ \\
\hline $121 \mathrm{R}-1$ & 344.80 & 507.292 & 403.000 & 467.500 & 401.109 & B \\
\hline $122 \mathrm{R}-1$ & 347.90 & 513.248 & 419.000 & 467.500 & 552.958 & A \\
\hline $123 \mathrm{R}-1$ & 350.81 & 806.114 & 524.000 & 467.500 & 861.872 & D \\
\hline 124R-1 & 353.62 & 412.030 & 377.000 & 407.000 & 276.268 & A \\
\hline $125 \mathrm{R}-1$ & 354.46 & 649.127 & 407.000 & 935.500 & 810.383 & G \\
\hline $125 \mathrm{R}-1$ & 354.83 & 744.819 & 464.000 & 234.000 & 789.069 & G \\
\hline 126R-1 & 356.72 & 478.000 & 422.000 & 407.000 & 283.698 & C \\
\hline $127 \mathrm{R}-1$ & 359.61 & 43.920 & 34.395 & 41.895 & 36.798 & 6 \\
\hline $127 \mathrm{R}-1$ & 359.93 & 36.397 & 28.239 & 36.618 & 31.418 & 6 \\
\hline $129 \mathrm{R}-1$ & 366.06 & 589.121 & 507.000 & 467.500 & 318.420 & C \\
\hline $129 \mathrm{R}-2$ & 367.56 & 571.579 & 486.000 & 467.500 & 309.019 & C \\
\hline 130R-1 & 369.14 & 788.478 & 492.000 & 407.000 & 782.154 & C \\
\hline $132 \mathrm{R}-1$ & 373.23 & 562.475 & 500.000 & 467.500 & 275.733 & C \\
\hline 133R-1 & 375.19 & 595.376 & 452.000 & 354.500 & 422.977 & C \\
\hline 133R-2 & 376.69 & 448.739 & 383.000 & 354.500 & 245.423 & C \\
\hline 134R-1 & 378.24 & 904.250 & 643.000 & 354.500 & 756.912 & $\mathrm{H}$ \\
\hline 134R-2 & 379.73 & 510.415 & 436.000 & 379.000 & 282.431 & C \\
\hline 135R-1 & 381.31 & 551.084 & 450.000 & 407.000 & 358.587 & C \\
\hline $135 \mathrm{R}-2$ & 382.81 & 601.360 & 465.000 & 407.000 & 411.135 & C \\
\hline 136R-1 & 384.36 & 485.779 & 420.000 & 407.000 & 282.129 & C \\
\hline 136R-2 & 385.84 & 623.567 & 477.000 & 407.000 & 434.328 & C \\
\hline 137R-1 & 387.44 & 529.663 & 427.000 & 354.500 & 348.347 & C \\
\hline 137R-2 & 388.94 & 446.142 & 383.000 & 354.500 & 236.282 & C \\
\hline 138R-1 & 390.79 & 447.137 & 384.000 & 354.500 & 249.777 & C \\
\hline 138R-2 & 392.26 & 468.471 & 397.000 & 354.500 & 300.438 & C \\
\hline 139R-1 & 393.51 & 452.872 & 364.000 & 308.500 & 302.177 & C \\
\hline 140R-1 & 396.61 & 563.699 & 433.000 & 354.500 & 407.228 & C \\
\hline 140R-2 & 398.03 & 510.219 & 421.000 & 354.500 & 292.853 & C \\
\hline 141R-1 & 399.61 & 417.556 & 363.000 & 354.500 & 213.759 & C \\
\hline 142R-1 & 402.68 & 374.966 & 344.000 & 354.500 & 186.318 & B \\
\hline $142 \mathrm{R}-2$ & 404.18 & 357.518 & 338.000 & 354.500 & 176.583 & B \\
\hline 143R-1 & 405.71 & 19.008 & 10.964 & 14.146 & 23.131 & 2 \\
\hline 144R-1 & 408.62 & 275.399 & 276.000 & 308.500 & 107.019 & B \\
\hline 144R-2 & 410.12 & 86.476 & 34.706 & 186.794 & 102.927 & 16 \\
\hline 145R-1 & 411.86 & 107.201 & 45.906 & 214.006 & 121.233 & 16 \\
\hline $145 \mathrm{R}-2$ & 413.36 & 39.593 & 23.598 & 16.235 & 40.315 & 14 \\
\hline 146R-1 & 414.99 & 31.173 & 19.012 & 16.249 & 33.008 & 13 \\
\hline $146 \mathrm{R}-2$ & 416.49 & 39.295 & 28.698 & 36.673 & 35.396 & 10 \\
\hline 147R-1 & 418.09 & 33.451 & 21.289 & 27.941 & 33.807 & 9 \\
\hline $147 R-2$ & 419.58 & 32.548 & 23.127 & 31.984 & 30.229 & 10 \\
\hline $148 \mathrm{R}-1$ & 421.06 & 35.604 & 27.668 & 36.646 & 30.457 & 6 \\
\hline $149 \mathrm{R}-1$ & 424.29 & 36.019 & 25.859 & 32.028 & 33.109 & 10 \\
\hline 150R-1 & 427.06 & 24.913 & 18.626 & 24.404 & 22.624 & 10 \\
\hline 151R-1 & 430.36 & 28.470 & 23.034 & 31.949 & 23.721 & 6 \\
\hline $152 \mathrm{R}-1$ & 433.21 & 30.309 & 25.274 & 32.070 & 24.168 & 6 \\
\hline 153R-1 & 436.26 & 26.597 & 20.117 & 27.938 & 23.800 & 6 \\
\hline 154R-1 & 439.92 & 30.377 & 24.858 & 32.060 & 24.818 & 6 \\
\hline $155 \mathrm{R}-2$ & 443.79 & 27.071 & 22.471 & 28.032 & 21.538 & 6 \\
\hline 156R-1 & 445.41 & 34.567 & 29.060 & 36.692 & 27.444 & 6 \\
\hline 157R-1 & 448.41 & 31.930 & 26.905 & 36.589 & 25.095 & 6 \\
\hline 158R-1 & 451.47 & 28.244 & 23.124 & 31.924 & 23.041 & 6 \\
\hline $159 \mathrm{R}-2$ & 456.26 & 26.756 & 21.218 & 28.012 & 22.912 & 6 \\
\hline 160R-1 & 457.56 & 26.203 & 20.340 & 27.961 & 23.022 & 6 \\
\hline $161 \mathrm{R}-1$ & 460.76 & 27.515 & 21.366 & 27.976 & 23.955 & 6 \\
\hline $162 \mathrm{R}-1$ & 463.69 & 26.924 & 20.993 & 27.985 & 23.383 & 6 \\
\hline 165R-1 & 473.13 & 29.190 & 20.078 & 27.911 & 28.730 & 10 \\
\hline $165 \mathrm{R}-2$ & 474.24 & 30.323 & 20.038 & 24.390 & 30.269 & 9 \\
\hline 166R-1 & 476.36 & 33.514 & 22.576 & 27.954 & 32.870 & 9 \\
\hline $166 \mathrm{R}-2$ & 477.90 & 36.836 & 26.937 & 32.003 & 33.763 & 10 \\
\hline 167R-1 & 478.91 & 35.590 & 21.083 & 21.267 & 38.666 & 13 \\
\hline $167 \mathrm{R}-2$ & 480.39 & 29.346 & 21.380 & 24.378 & 27.263 & 6 \\
\hline $168 \mathrm{R}-1$ & 481.96 & 26.025 & 19.567 & 21.356 & 23.703 & 6 \\
\hline $168 \mathrm{R}-2$ & 483.49 & 27.919 & 19.511 & 21.338 & 27.488 & 6 \\
\hline $169 \mathrm{R}-1$ & 485.00 & 23.984 & 17.677 & 21.317 & 22.292 & 6 \\
\hline $169 \mathrm{R}-2$ & 486.79 & 21.991 & 12.737 & 14.151 & 26.808 & 7 \\
\hline 170R-1 & 488.15 & 26.605 & 16.314 & 18.581 & 30.579 & 7 \\
\hline
\end{tabular}

Type of distribution = distribution of grain-size frequencies: silt Types 1-16 (Fig. F2) and sand Types A-H (Fig. F3). 
Table T2. Grain-size analysis data, Hole M0028A. (Continued on next page.)

\begin{tabular}{|c|c|c|c|c|c|c|}
\hline \multirow[b]{2}{*}{ Core, section } & \multirow{2}{*}{$\begin{array}{l}\text { Depth } \\
\text { (mcd) }\end{array}$} & \multicolumn{4}{|c|}{ Grain size $(\mu \mathrm{m})$} & \multirow{2}{*}{$\begin{array}{c}\text { Type of } \\
\text { distribution }\end{array}$} \\
\hline & & Mean & Median & Mode & $\sigma$ & \\
\hline \multicolumn{7}{|l|}{ 313-M0028A- } \\
\hline $14 \mathrm{R}-1$ & 257.47 & 542.3 & 461.0 & 407.0 & 305.1 & $\mathrm{C}$ \\
\hline $15 \mathrm{R}-1$ & 260.38 & 631.0 & 494.0 & 467.5 & 458.6 & $\mathrm{C}$ \\
\hline $16 \mathrm{R}-1$ & 263.11 & 707.0 & 588.0 & 467.5 & 430.5 & $B$ \\
\hline 18R-1 & 266.28 & 448.6 & 401.0 & 407.0 & 282.1 & $B$ \\
\hline 19R-1 & 269.63 & 30.3 & 20.5 & 21.3 & 30.8 & 6 \\
\hline 20R-1 & 272.17 & 30.1 & 21.2 & 24.4 & 28.6 & 6 \\
\hline 21R-1 & 275.00 & 26.3 & 21.4 & 28.0 & 21.6 & 6 \\
\hline $21 \mathrm{R}-2$ & 276.45 & 742.3 & 500.0 & 467.5 & 712.9 & $\mathrm{~F}$ \\
\hline $22 \mathrm{R}-1$ & 278.25 & 41.2 & 30.0 & 48.1 & 37.1 & 10 \\
\hline $22 \mathrm{R}-2$ & 279.76 & 25.1 & 19.0 & 21.3 & 22.6 & 6 \\
\hline $24 \mathrm{R}-1$ & 284.28 & 21.5 & 14.6 & 21.3 & 22.9 & 1 \\
\hline $25 \mathrm{R}-1$ & 287.24 & 29.2 & 19.2 & 21.3 & 29.5 & 7 \\
\hline $27 R-1$ & 290.55 & 31.3 & 17.2 & 14.2 & 34.8 & 8 \\
\hline $27 R-2$ & 292.07 & 30.3 & 17.0 & 14.2 & 33.2 & 8 \\
\hline $29 R-1$ & 297.57 & 25.6 & 15.9 & 14.2 & 27.3 & 7 \\
\hline $29 R-2$ & 298.54 & 24.5 & 16.1 & 18.6 & 24.7 & 7 \\
\hline $30 \mathrm{R}-1$ & 297.68 & 31.4 & 18.7 & 14.2 & 33.2 & 8 \\
\hline 31R-1 & 299.69 & 27.0 & 17.0 & 18.6 & 28.0 & 7 \\
\hline $32 \mathrm{R}-1$ & 303.51 & 21.3 & 15.7 & 21.2 & 19.9 & 6 \\
\hline $33 R-1$ & 305.90 & 20.5 & 14.9 & 18.6 & 19.3 & 6 \\
\hline $34 \mathrm{R}-1$ & 309.79 & 20.5 & 15.9 & 21.3 & 17.9 & 6 \\
\hline $34 \mathrm{R}-2$ & 310.88 & 25.2 & 18.2 & 21.3 & 23.7 & 6 \\
\hline $35 R-1$ & 311.92 & 26.8 & 19.4 & 27.9 & 24.7 & 10 \\
\hline $35 \mathrm{R}-1$ & 312.83 & 28.2 & 19.3 & 24.4 & 27.6 & 10 \\
\hline $35 R-2$ & 313.22 & 24.4 & 15.7 & 16.2 & 25.9 & 7 \\
\hline $35 \mathrm{R}-2$ & 313.75 & 22.5 & 17.7 & 24.4 & 19.1 & 6 \\
\hline $37 R-2$ & 319.69 & 20.0 & 15.2 & 21.3 & 17.9 & 6 \\
\hline $38 \mathrm{R}-1$ & 321.20 & 32.3 & 20.4 & 21.3 & 33.2 & 7 \\
\hline $38 \mathrm{R}-2$ & 322.55 & 32.3 & 20.4 & 21.3 & 33.2 & 6 \\
\hline 79R-1 & 412.85 & 233.1 & 228.0 & 234.0 & 97.0 & $A$ \\
\hline $79 R-2$ & 414.35 & 261.2 & 246.0 & 268.5 & 124.8 & A \\
\hline 80R-1 & 416.64 & 50.1 & 28.4 & 24.4 & 53.8 & 13 \\
\hline $80 \mathrm{R}-2$ & 418.40 & 42.9 & 25.2 & 24.4 & 46.2 & 13 \\
\hline 81R-1 & 420.33 & 45.6 & 28.7 & 27.9 & 46.0 & 13 \\
\hline $81 R-2$ & 421.33 & 31.5 & 23.2 & 28.0 & 28.9 & 10 \\
\hline $82 \mathrm{R}-1$ & 424.13 & 33.0 & 23.0 & 28.0 & 31.9 & 10 \\
\hline $82 \mathrm{R}-2$ & 425.67 & 39.8 & 26.0 & 27.9 & 39.2 & 13 \\
\hline 83R-1 & 427.36 & 27.0 & 19.7 & 27.9 & 24.8 & 10 \\
\hline $83 R-2$ & 428.66 & 45.1 & 28.0 & 27.9 & 46.1 & 13 \\
\hline $84 \mathrm{R}-1$ & 430.69 & 31.8 & 24.6 & 32.0 & 27.6 & 6 \\
\hline $84 \mathrm{R}-2$ & 432.01 & 26.8 & 19.5 & 27.9 & 24.9 & 6 \\
\hline $85 R-1$ & 434.02 & 33.7 & 27.9 & 24.4 & 33.7 & 10 \\
\hline $85 R-2$ & 435.56 & 43.9 & 30.7 & 48.1 & 40.9 & 10 \\
\hline 86R-1 & 436.93 & 31.2 & 19.3 & 21.3 & 32.8 & 7 \\
\hline $86 \mathrm{R}-2$ & 438.54 & 36.0 & 23.4 & 32.0 & 35.6 & 9 \\
\hline 87R-1 & 440.13 & 36.2 & 20.5 & 16.2 & 39.4 & 13 \\
\hline $87 R-2$ & 441.63 & 34.0 & 22.4 & 28.0 & 33.8 & 10 \\
\hline $88 \mathrm{R}-2$ & 444.80 & 30.3 & 19.8 & 24.4 & 30.6 & 10 \\
\hline $89 R-2$ & 447.82 & 27.0 & 20.5 & 28.0 & 24.2 & 6 \\
\hline 91R-1 & 452.58 & 27.2 & 20.3 & 31.9 & 24.6 & 6 \\
\hline 92R-1 & 456.01 & 26.4 & 19.8 & 28.0 & 24.0 & 6 \\
\hline 93R-1 & 458.79 & 29.7 & 21.7 & 32.0 & 27.5 & 6 \\
\hline 94R-1 & 461.47 & 27.3 & 20.2 & 28.0 & 24.8 & 6 \\
\hline 95R-1 & 464.59 & 34.2 & 22.8 & 36.6 & 33.8 & 10 \\
\hline 96R-1 & 467.43 & 30.3 & 22.7 & 32.0 & 27.5 & 6 \\
\hline 97R-1 & 470.67 & 28.6 & 21.3 & 32.0 & 26.0 & 6 \\
\hline 98R-1 & 473.64 & 26.0 & 18.7 & 27.9 & 24.6 & 10 \\
\hline 99R-1 & 476.81 & 27.6 & 17.6 & 21.3 & 29.0 & 7 \\
\hline 99R-2 & 478.31 & 26.0 & 18.9 & 27.9 & 24.4 & 6 \\
\hline 100R-1 & 479.75 & 24.3 & 18.5 & 27.9 & 21.5 & 6 \\
\hline $101 \mathrm{R}-2$ & 483.96 & 26.6 & 20.6 & 32.0 & 23.4 & 6 \\
\hline $102 \mathrm{R}-2$ & 487.38 & 26.4 & 19.6 & 27.9 & 23.9 & 6 \\
\hline 103R-1 & 488.91 & 24.3 & 18.5 & 27.9 & 21.3 & 6 \\
\hline 104R-1 & 492.01 & 21.2 & 15.3 & 18.6 & 19.7 & 6 \\
\hline 105R-1 & 495.56 & 22.2 & 17.1 & 21.4 & 19.5 & 6 \\
\hline 106R-1 & 498.54 & 30.1 & 19.8 & 21.3 & 29.9 & 7 \\
\hline 107R-1 & 501.41 & 25.7 & 17.6 & 24.4 & 25.1 & 10 \\
\hline
\end{tabular}


Table T2 (continued).

\begin{tabular}{|c|c|c|c|c|c|c|}
\hline \multirow[b]{2}{*}{ Core, section } & \multirow{2}{*}{$\begin{array}{l}\text { Depth } \\
\text { (mcd) }\end{array}$} & \multicolumn{4}{|c|}{ Grain size $(\mu \mathrm{m})$} & \multirow{2}{*}{$\begin{array}{c}\text { Type of } \\
\text { distribution }\end{array}$} \\
\hline & & Mean & Median & Mode & $\sigma$ & \\
\hline 107R-2 & 503.03 & 34.4 & 23.7 & 36.7 & 33.2 & 10 \\
\hline 108R-2 & 505.53 & 27.3 & 20.3 & 28.0 & 25.0 & 6 \\
\hline 109R-1 & 507.34 & 28.0 & 21.1 & 24.4 & 25.6 & 6 \\
\hline $109 \mathrm{R}-2$ & 508.87 & 25.9 & 20.9 & 24.4 & 21.7 & 6 \\
\hline $110 \mathrm{R}-1$ & 509.99 & 23.3 & 18.4 & 21.4 & 19.7 & 6 \\
\hline $110 \mathrm{R}-2$ & 511.51 & 24.6 & 17.2 & 18.6 & 24.8 & 6 \\
\hline $111 \mathrm{R}-1$ & 513.52 & 24.3 & 19.8 & 24.4 & 19.8 & 6 \\
\hline $111 \mathrm{R}-2$ & 515.04 & 34.0 & 23.9 & 24.5 & 32.5 & 6 \\
\hline $112 \mathrm{R}-1$ & 516.62 & 29.1 & 20.2 & 21.3 & 28.8 & 6 \\
\hline $112 \mathrm{R}-2$ & 518.02 & 25.1 & 14.4 & 14.2 & 29.3 & 7 \\
\hline $113 R-1$ & 519.27 & 24.0 & 14.9 & 16.3 & 27.6 & 1 \\
\hline $113 R-1$ & 520.02 & 21.3 & 16.7 & 24.3 & 18.4 & 6 \\
\hline $114 \mathrm{R}-1$ & 522.45 & 21.7 & 15.3 & 21.3 & 22.2 & 1 \\
\hline
\end{tabular}

Type of distribution = distribution of grain-size frequencies: silt Types 1-16 (Fig. F2) and sand Types A-H (Fig. F3). 
Table T3. Grain-size analysis data, Hole M0029A.

\begin{tabular}{|c|c|c|c|c|c|c|}
\hline \multirow[b]{2}{*}{ Core, section } & \multirow{2}{*}{$\begin{array}{l}\text { Depth } \\
\text { (mcd) }\end{array}$} & \multicolumn{4}{|c|}{ Grain size $(\mu \mathrm{m})$} & \multirow{2}{*}{$\begin{array}{c}\text { Type of } \\
\text { distribution }\end{array}$} \\
\hline & & Mean & Median & Mode & $\sigma$ & \\
\hline \multicolumn{7}{|l|}{ 313-M0029A- } \\
\hline 50R-1 & 280.49 & 193.9 & 185.0 & 203.5 & 66.7 & B \\
\hline 50R-2 & 282.00 & 27.2 & 11.8 & 9.5 & 36.7 & 3 \\
\hline 51R-1 & 283.61 & 785.9 & 180.0 & 177.0 & 2003.2 & B \\
\hline 53R-1 & 289.64 & 40.8 & 22.9 & 16.2 & 42.6 & 14 \\
\hline $53 \mathrm{R}-2$ & 291.14 & 18.0 & 13.8 & 16.2 & 16.3 & 6 \\
\hline 56R-1 & 294.95 & 203.4 & 175.0 & 154.5 & 119.1 & B \\
\hline 57R-1 & 298.80 & 213.1 & 191.0 & 190.3 & 102.8 & B \\
\hline 57R-2 & 300.14 & 280.5 & 266.0 & 268.5 & 114.1 & B \\
\hline 58R-1 & 301.91 & 347.8 & 264.0 & 268.5 & 475.5 & A \\
\hline 59R-1 & 304.90 & 280.2 & 272.0 & 308.5 & 103.4 & A \\
\hline $59 \mathrm{R}-2$ & 306.42 & 234.7 & 200.0 & 190.3 & 129.2 & B \\
\hline 60R-1 & 308.58 & 227.0 & 179.0 & 177.0 & 247.4 & B \\
\hline $60 \mathrm{R}-2$ & 310.08 & 66.1 & 44.3 & 108.4 & 65.5 & 15 \\
\hline 61R-1 & 311.06 & 79.9 & 53.5 & 124.3 & 80.9 & 15 \\
\hline 61R-2 & 312.56 & 81.8 & 44.1 & 142.5 & 88.4 & 16 \\
\hline $62 \mathrm{R}-1$ & 314.11 & 27.3 & 18.4 & 21.3 & 27.7 & 10 \\
\hline 63R-1 & 317.18 & 61.4 & 31.6 & 124.3 & 66.5 & 16 \\
\hline 64R-1 & 320.36 & 95.6 & 42.7 & 186.7 & 109.6 & 16 \\
\hline 65R-1 & 323.58 & 47.2 & 27.2 & 18.6 & 48.7 & 14 \\
\hline $65 \mathrm{R}-2$ & 324.96 & 34.7 & 22.8 & 24.4 & 34.5 & 9 \\
\hline 66R-1 & 326.49 & 17.1 & 12.4 & 16.2 & 16.1 & 2 \\
\hline 67R-1 & 329.22 & 34.2 & 26.4 & 41.9 & 29.9 & 6 \\
\hline 67R-2 & 330.76 & 24.7 & 19.5 & 27.9 & 20.9 & 6 \\
\hline 69R-1 & 335.59 & 16.7 & 12.3 & 16.2 & 15.4 & 6 \\
\hline $69 \mathrm{R}-2$ & 336.95 & 16.0 & 12.2 & 16.2 & 13.8 & 4 \\
\hline 70R-2 & 340.09 & 16.9 & 13.4 & 18.6 & 14.2 & 5 \\
\hline 71R-1 & 341.89 & 23.4 & 18.2 & 24.4 & 20.3 & 6 \\
\hline $72 \mathrm{R}-2$ & 345.16 & 50.3 & 28.1 & 21.3 & 54.1 & 14 \\
\hline 73R-1 & 346.77 & 44.7 & 30.4 & 63.2 & 42.5 & 11 \\
\hline 73R-2 & 348.27 & 67.4 & 58.8 & 72.4 & 51.9 & 12 \\
\hline 74R-1 & 350.69 & 30.3 & 22.5 & 32.0 & 27.6 & 10 \\
\hline 76R-1 & 354.73 & 87.7 & 78.1 & 108.2 & 70.3 & 12 \\
\hline 77R-1 & 356.81 & 60.7 & 42.8 & 94.5 & 58.3 & 15 \\
\hline 78R-1 & 359.86 & 74.0 & 65.0 & 82.9 & 57.6 & 12 \\
\hline 78R-2 & 361.39 & 51.8 & 42.6 & 63.1 & 43.1 & 12 \\
\hline 79R-1 & 363.06 & 55.3 & 45.3 & 72.0 & 47.1 & 12 \\
\hline 80R-1 & 366.25 & 20.0 & 13.9 & 16.2 & 19.8 & 6 \\
\hline 81R-2 & 370.68 & 22.5 & 15.4 & 21.3 & 22.5 & 6 \\
\hline 82R-1 & 372.60 & 22.4 & 15.6 & 18.6 & 22.2 & 6 \\
\hline 84R-1 & 378.10 & 26.0 & 20.5 & 27.9 & 22.6 & 6 \\
\hline $111 \mathrm{R}-1$ & 457.65 & 17.9 & 11.5 & 10.8 & 19.2 & 7 \\
\hline $112 \mathrm{R}-1$ & 460.97 & 21.9 & 13.7 & 14.2 & 23.4 & 7 \\
\hline $113 \mathrm{R}-1$ & 464.15 & 344.7 & 293.0 & 268.5 & 204.6 & B \\
\hline $114 \mathrm{R}-1$ & 466.69 & 38.0 & 24.0 & 55.0 & 37.5 & 11 \\
\hline $114 \mathrm{R}-2$ & 468.19 & 50.1 & 32.2 & 72.4 & 49.5 & 11 \\
\hline 115R-1 & 469.73 & 28.1 & 18.9 & 21.3 & 28.2 & 10 \\
\hline 116R-1 & 472.71 & 314.1 & 279.0 & 268.5 & 161.8 & B \\
\hline 116R-2 & 474.21 & 266.2 & 241.0 & 234.0 & 134.7 & B \\
\hline 117R-1 & 475.61 & 95.0 & 29.5 & 214.6 & 120.1 & 16 \\
\hline 117R-2 & 477.11 & 36.5 & 23.5 & 28.0 & 36.7 & 9 \\
\hline 118R-1 & 478.78 & 14.8 & 10.1 & 10.8 & 16.5 & 4 \\
\hline $120 \mathrm{R}-2$ & 483.29 & 33.4 & 19.5 & 14.2 & 35.4 & 8 \\
\hline 123R-2 & 492.56 & 28.2 & 18.9 & 21.3 & 29.1 & 6 \\
\hline 127R-2 & 504.06 & 29.3 & 18.2 & 16.2 & 30.2 & 9 \\
\hline $128 \mathrm{R}-1$ & 506.41 & 38.5 & 24.7 & 55.1 & 37.6 & 11 \\
\hline $129 \mathrm{R}-1$ & 509.57 & 27.5 & 18.7 & 24.4 & 26.9 & 7 \\
\hline 130R-2 & 513.68 & 45.6 & 26.2 & 82.6 & 47.3 & 11 \\
\hline $131 \mathrm{R}-2$ & 517.30 & 27.2 & 15.5 & 14.2 & 29.9 & 8 \\
\hline $132 \mathrm{R}-1$ & 519.09 & 24.3 & 14.4 & 14.2 & 26.8 & 7 \\
\hline 133R-1 & 521.42 & 26.8 & 17.7 & 27.9 & 27.2 & 10 \\
\hline
\end{tabular}

Type of distribution = distribution of grain-size frequencies: silt Types 1-16 (Fig. F2) and sand Types A-H (Fig. F3). 
Table T4. Distribution of grain-size frequency types, Sites M0027, M0028, and M0029.

\begin{tabular}{|c|c|c|c|c|c|c|c|c|}
\hline \multirow[b]{2}{*}{ Type } & \multicolumn{2}{|c|}{ Site M0027 } & \multicolumn{2}{|c|}{ Site M0028 } & \multicolumn{2}{|c|}{ Site M0029 } & \multicolumn{2}{|c|}{ Sites M0027-M0029 } \\
\hline & Count & $\%$ & Count & $\%$ & Count & $\%$ & Subtotal & $\%$ \\
\hline 1 & 3 & 3.0 & 3 & 4.1 & 0 & 0.0 & 6 & 2.7 \\
\hline 2 & 3 & 3.0 & 0 & 0.0 & 1 & 2.1 & 4 & 1.8 \\
\hline 3 & 0 & 0.0 & 0 & 0.0 & 1 & 2.1 & 1 & 0.5 \\
\hline 4 & 2 & 2.0 & 0 & 0.0 & 2 & 4.2 & 4 & 1.8 \\
\hline 5 & 4 & 4.0 & 0 & 0.0 & 1 & 2.1 & 5 & 2.3 \\
\hline 6 & 53 & 53.5 & 36 & 49.3 & 10 & 20.8 & 99 & 45.0 \\
\hline 7 & 8 & 8.1 & 10 & 13.7 & 4 & 8.3 & 22 & 10.0 \\
\hline 8 & 1 & 1.0 & 3 & 4.1 & 2 & 4.2 & 6 & 2.7 \\
\hline 9 & 4 & 4.0 & 1 & 1.4 & 3 & 6.3 & 8 & 3.6 \\
\hline 10 & 14 & 14.1 & 14 & 19.2 & 4 & 8.3 & 32 & 14.5 \\
\hline 11 & 1 & 1.0 & 0 & 0.0 & 5 & 10.4 & 6 & 2.7 \\
\hline 12 & 0 & 0.0 & 0 & 0.0 & 5 & 10.4 & 5 & 2.3 \\
\hline 13 & 2 & 2.0 & 6 & 8.2 & 0 & 0.0 & 8 & 3.6 \\
\hline 14 & 2 & 2.0 & 0 & 0.0 & 3 & 6.3 & 5 & 2.3 \\
\hline 15 & 0 & 0.0 & 0 & 0.0 & 3 & 6.3 & 3 & 1.4 \\
\hline 16 & 2 & 2.0 & 0 & 0.0 & 4 & 8.3 & 6 & 2.7 \\
\hline Subtotal: & 99 & & 73 & & 48 & & 220 & \\
\hline A & 2 & 5.6 & 2 & 28.6 & 2 & 16.7 & 6 & 10.9 \\
\hline B & 7 & 19.4 & 2 & 28.6 & 10 & 83.3 & 19 & 34.5 \\
\hline C & 20 & 55.6 & 2 & 28.6 & & 0.0 & 22 & 40.0 \\
\hline D & 1 & 2.8 & & 0.0 & & 0.0 & 1 & 1.8 \\
\hline$E$ & 1 & 2.8 & & 0.0 & & 0.0 & 1 & 1.8 \\
\hline $\mathrm{F}$ & 2 & 5.6 & 1 & 14.3 & & 0.0 & 3 & 5.5 \\
\hline G & 2 & 5.6 & & 0.0 & & 0.0 & 2 & 3.6 \\
\hline $\mathrm{H}$ & 1 & 2.8 & & 0.0 & & 0.0 & 1 & 1.8 \\
\hline Subtotal: & 36 & & 7 & & 12 & & 55 & \\
\hline Total: & 135 & & 80 & & 60 & & 275 & \\
\hline
\end{tabular}

